\author{
JAVIER DÍAZ NOCI \\ Pompeu Fabra University \\ Faculty of Communication \\ Roc Boronat, 138 \\ 08018 Barcelona (Spain) \\ javier.diaz@upf.edu \\ $+34935421220$
}




\title{
Dissemination of News in the Spanish Baroque
}

\begin{abstract}
This text analyses the dissemination of news in the Spanish language throughout Europe during the seventeenth century, with attention given to the principal strategies put into effect by printers, publishers, entrepreneurs and newsmongers for printed newssheets. Concretely, it analyses how the emergence of several weekly newspapers occurred in the Low Countries, both in those areas under the Spanish monarchy (with Brussels as the main focus for the emission of news) and those that were not (with Amsterdam and the Jewish community originating from the Iberian peninsula as the basic news agents), and their reception and redistribution within Spain. Here, in their turn, certain cities stood out that, for various reasons, received and distributed news from several parts of Europe; these were principally Seville, San Sebastián and Barcelona, where, besides, genuine news offices were established.
\end{abstract}

\section{Keywords}

Netherlands. Spain. Distribution. Journalism. News network. Baroque. 


\section{Introduction: the State of the Question}

The practice of what would later be known as journalism was consolidated in Europe around 1620. By that year, a notable flow of information on the Continent had taken shape (Couvée, 1962; Dahl,1960). Corantoes in England were regularly produced from 1620 onwards (Raymond, 1996; Raymond, 2003). In Germany, journalism was already established at the start of the seventeenth century (Weber, 2010). In Spain, it is to 1618 that the publication in Seville of a gazette (understood as printed matter containing different news stories, not necessarily periodically, which would occur later) can be dated; this was the Gazeta romana y relacion general de avisos de todos los reynos y prouincias del mundo [Roman gazette and general newssheet of all the kingdoms and provinces of the world] of Francisco Serrano de Vargas. By 1627, the consumption of news was so great that Felipe IV was obliged to promulgate a law on June $13^{\text {th }}$, prohibiting the appearance of uncontrolled newspapers. This was unsuccessful until the end of the century, since printers from Madrid, Zaragoza, Valencia, Barcelona or San Sebastián managed in one way or another to find a way round that attempt by the monarchy to impose a de jure monopoly, since a de facto one was not possible.

A large, overarching and newsworthy event, the Thirty Years War, was pulling Europe into a new period of newspaper production. To provide some context for this article's main object of study, the production of newssheets in the Peninsula will be briefly examined, but the research will be concentrated on those Spanish-language gazettes that were produced at the end of the seventeenth century outside the frontiers of Spain, in Amsterdam and Brussels, and on their repercussion on the (re)production of news in Spain. This study will try to show the tensions to which the Spanish news market was subjected, and what its particularities were. At the same time, this article will attempt to enlarge on the studies that have been done on news production in those two important European news centers, Amsterdam and Brussels, where newspapers were published in many languages.

The following is a state of the art of the study of news in the Iberian Peninsula. In the absence of an in-depth study of the circulation of news in handwritten form in Spain, and

its coexistence with printed news, we are beginning to gain a deeper knowledge of the publication of news periodicals in the seventeenth century. For newssheets, the different 
volumes published by the Sociedad Internacional para el Estudio de las Relaciones de Sucesos [International Society for the Study of Newssheets] signal the full acceptance of studies of such ephemera that were for so long scorned, if not unknown. For the Catalan case, especially the Revolt of the Catalans (which in 1641 led to a brief period when Catalonia separated from the Spanish monarchy and was joined to France), there is the work of Henry Ettinghausen and Jaume Guillamet (2003). The same happened before 1640 with Portugal, which until that year was part of the Spanish kingdom. The first weekly gazette appeared in Lisbon in $1641^{\mathrm{i}}$.

We propose to explain the route followed by news, both within Spain, and the publication, distribution and adaptation of entire items published in Spanish beyond the Spanish frontiers ${ }^{\mathrm{ii}}$. This is, without doubt, a work to be developed, following in the wake of Dooley (2010) in order to explain the system of the means of journalism in the Baroque (we take the concept from Bastiansen, 2008). As has been made clear by professor Infelise, the same news stories circulated throughout Europe, in printed or handwritten form ${ }^{\text {iii }}$, through a network of correspondents who made good use of the postal services of Europe. This strengthened the flow of news; as Paul Arblaster reminds us, the urban nuclei of Italy and the Low Countries were connected to the principal nodes of communication of the rest of the continent, and another route joined Trent and Brussels with Frankfurt, Cologne and other German cities, all under the administration of the Tassis family, which had a virtual monopoly of the European post (Arblaster, 2006: 21). This defined "a definitive treatment of the spread of news in seventeenth-century Europe [which] is still a project for future generations of scholars" (Maier, Waugh, 2007: 1).

Spain had a specific character as it was an ensemble of kingdoms with their own juridical traditions, laws and languages, which had resulted from the union of the kingdoms of Aragon and Castile in the period of the Catholic Monarchs, from the heritage of their grandson, the emperor Charles $\mathrm{V}$, and from the discovery and conquest of vast territories in America. This meant that Spain was a country whose power extended over immense territories. But, at the same time, the wars of religion, the difficulty in maintaining political and economic cohesion in continental and overseas territories, and the breakup of the empire, had made Spain into a state that was only relatively united; its enormous contradictions and weaknesses also found reflection in the difficulties for consolidating a 
solid news market. A panorama that was to a certain extent fragmented, with numerous internal and external differences and influences, can be discerned. These are the questions what will be analyzed in this paper.

\section{The Circulation of Spanish Gazettes in Europe}

\subsection{Evolution of the Spanish news market}

The Spanish news panorama consisted in the production of mainly printed (and some occasional manuscript) newssheets until practically 1661, which was when Francisco Fabro Bremundán gave a stable name and periodicity to his Gazeta Nueva [New Gazette]. Until that time, the Crown, employing strategies that were more informal than official in character, had managed to use the emergent press as a means for transmitting its ideology, and the Count-Duke of Olivares was an expert in this respect (Díaz Noci, 2004). Clear examples of this practice are found in news concerning the siege of Hondarriba in 16381639 , and in the proliferation of news stories of every type, in prose and verse, official and unofficial, serious and humorous, some of them penned by names like Francisco de Quevedo.

Unlike other European countries, the undertaking was not directly linked to the monarchy, but was, we could say, an undertaking that was illegitimate, like its promoter, Juan José de Austria, the bastard son of the king Felipe IV. The centre for the emission of news par excellence from the end of the sixteenth to the start of the seventeenth centuries was Seville, due to the energies of both Rodrigo de Cabrera (Espejo, 2008b: 30-31) and Juan Serrano de Vargas - not to mention the wealthy status of its bourgeoisie due to the commercial links with America, whose silver entered Spain through the city. Serrano de Vargas was the author of numerous printed newssheets between 1617 and 1625 (Espejo, 2009b: 41-43). The strategy of serialisation was also due to him, that is, newssheets

containing stories linked to a single theme, which were published while the event was of current relevance -not unusual in some other parts of the Continent (Pettegree, 2010). 
However, the leap to periodicity in Seville did not take place until years later. It was to be Juan Gómez de Blas, who first republished Bremundán's Madrid-based Gazeta Nueva with numerous modifications, adaptations and innovations between 1661 and 1667 (Espejo, 2008), but who did not publish a completely original newspaper, the Gazeta Sevillana [Seville Gazette], until 1697.

Barcelona had a dynamic market from 1641 onwards, with the different publications of the Matevat family and Jaume Romeu, although these were translations from French rather than original initiatives. However, it was in the 1680s when the leap was made to the original and continued production of weeklies across Spain: Noticias Generales de Europa [General News of Europe], whose content arrived by post from different places (Italy, Flanders, France), between 1680 and 1702, at least, through the work of the printers Rafael Figueró and Jacinto Andreu, but also of others, which leads one to think of the possible existence of a commercial agreement, or syndicate, existing amongst them ${ }^{\text {iv }}$ (Díaz Noci, 2004).

Another two cities became important foci of news in Spain in this period: Madrid and Saragossa. In both, the newsmonger and chronicler Francisco Fabro Bremundán plied his trade, following his lord, Juan José de Austria. Born Faivre Bremondans in Burgundy in 1621, Bremundán was in charge of a translation office from 1656 onwards, when Juan José de Austria made his acquaintance. He began to edit a serialised paper in 1660, which was first titled Relación o gazeta de algunos casos particulares [Newssheet or gazette of some particular cases] and was published until 1662 under that or other names (above all Gazeta Nueva [New Gazette]). Bremundán accompanied his lord, who was appointed General Deputy of the Kingdom of Aragon, to Saragossa, where between 1663 and 1676 he published some other newssheets (Lamarque, 1971). From there, Juan José de Austria returned to Madrid, and with him went the loyal Bremundán, who once again published another newspaper, the Gazeta Ordinaria de Madrid [Ordinary Gazette of Madrid], until 1680. Juan José de Austria had by then died in 1679. From 1677 onwards, Bremundán was the official newsmonger of the realm, which his contemporaries treated as a joke, although in this way he obtained the monopoly of news production ${ }^{\mathrm{v}}$.

The Spanish news panorama only began to become stabilised from this time onwards. Until his death in 1698, Francisco Fabro worked in a syndicate with the publisher Sebastián de 
Armendáriz, an extraordinarily dynamic figure who was involved in the publication of newssheets, both serialised and periodical. Some other publishers joined Bremundán and Armendáriz: in 1684, a Gazeta General del Norte, Italia, y otras partes [General Gazette of the North, Italy and other parts] came out in Madrid, published by Lucas Antonio de Bedmar y Valdivia (Díaz Noci and Del Hoyo, 2003: 43-44). Only one year before the death of Bremundán, the Gazeta de Madrid appeared with this name, on April $2^{\text {nd }} 1697$, produced by Juan de las Heras, a former collaborator and who from 1696 onwards established a commercial relationship with Juan de Goyeneche, to whom the Crown granted the privilege of publishing and printing the newspaper.

For a large part of the seventeenth century, news production in Spain was therefore characterized by a tension between the centre - where there were (weak) attempts to monopolize the diffusion of news by the monarchy - and the periphery. This was above all true in those parts of the kingdoms of Spain where other laws enabled easier access to news and its reproduction. Saragossa, Barcelona and, to a lesser extent, Valencia, the principal cities of the Kingdom of Aragon; San Sebastián, a Basque city which thus had its own laws [fueros] and was located closer to France; and Seville, the main center of trade with America were clear examples. It proved impossible for the monarchy to promote and effectively control the emerging trade in news. This explains why a monopoly (or in reality a quasi-monopoly) was given to individuals who were close to the institution but did not form part of it (the bastard Juan José de Austria and his servant Francisco Fabro Bremundán), and why this monopoly finally came under the control of the private initiative of Juan de Goyeneche. To this must be added the production and diffusion of news in the Spanish language from outside the frontiers of the kingdom. We are referring to those put out by the Jewish community in Amsterdam and the publication - probably as a reaction to this news centre - of unofficial news in Brussels. These publications were in their turn reproduced in those cities of Spain that were less susceptible to the monopolizing attempts of the Hapsburg monarchy: San Sebastián, Barcelona and Seville. Paradoxically, a significant part of the public in the Peninsula had to obtain news from production centers located a considerable distance away, and depended on the news traffic proceeding from central Europe. 


\subsection{Spanish Journalism outside Spain: The Amsterdam Gazette}

In 1639, in Amsterdam the Talmud Torah community was founded, formed by Jews of Iberian origin. This community of cultured people, belonging to the commercial bourgeoisie, as Harm de Boer has shown, was to be of importance for journalism in the Spanish language. This was because in 1675, and at least until 1691, it published the first Jewish newspaper, and it did so in the Spanish language - in the contemporary variant, not in the judezmo of the Sephardic community - possibly on the initiative of its printer, David de Castro Tartás. His activity as a book printer is documented from 1663 onwards, and became more intense in precisely those years when he began to publish his gazette.

The first issue of the Gazeta de Amsterdam dates from Monday $7^{\text {th }}$ January 1675 . The information has been obtained from the copies belonging to the collection of the Royal Library of Holland (Koninklijke Bibliotheek), which includes several consecutive weekly issues from the year 1675 and a single issue from 1690, this latter issue titled Gazeta española de Amsterdam [Spanish Gazette of Amsterdam] in clear reference to the Spanish language and not to the nation - which is also the sense in which the word is employed in this research; and the collection found in the Hemeroteca Municipal de Madrid, which includes issues from 1690 (six numbers) and 1691 (seven numbers).

Compared with the contemporary gazettes from the other countries, of poorer presentation, including the Spanish ones, which were always printed in a single column, David de Castro's weekly is perfectly comparable to the other Dutch gazettes that came off the presses of the big newspaper printers of the time (Dahl, 1946). The Gazeta de Amsterdam was designed in two columns, with headlines in capital letters by country (Italy, France, Germany, Flanders and Holland) and subtitles in italics indicating the city and date (Venecia, 23 Deziembre, for example). This double column design was typical of the Dutch gazettes - and also of the London Gazette - and was started by the Courante uyt Italien, Duytslandt, \&c., a design that was, in its turn, taken from the popular (Protestant) editions of the Bible. Each weekly copy invariably consisted of four pages, at the end of which figures the printer's imprint: «Impresso en Casa de David Tartás». This simple but

functional design was maintained until 1690, when, besides the abovementioned 
pagination, a page heading was incorporated that read «Gazeta española de Amsterdam [Spanish Gazette of Amsterdam] ».

Besides the more usual international news, from Italy, Germany, France and England, the gazette reported punctually on what was happening in Brussels (which leads one to think that it was read with some diligence) and in Holland. Reporting on the domestic affairs of the country itself was not at all usual in nations like Spain or France, where the press was subjected to the iron control of royal censorship. David de Castro Tartás provided news of Amsterdam and the Hague.

With respect to regularity of the information offered to the audience, this naturally depended on the distance of the cities where the information was produced. It took between two and three weeks to arrive from Italy, between one and two weeks from France, Germany and London. Only a few days separate the dating of news from the Hague and Brussels. Many of the news stories from Amsterdam are very recent, dating from the same day as the newspaper came out. The latter was therefore composed, printed and distributed in a single day, which was always a Monday.

It was aimed at a public that was not exclusively Jewish (anyone who could read in Spanish, and the number was not inconsiderable), but not the Iberian public (the gazette did not reach Spain or Portugal, at least not in a legal way). It is clear that this was not even attempted: against what was then a fairly common practice, the printer's imprint was an exact reflection of reality ${ }^{\text {vi }}$.

\subsection{Brussels, a City Producing Spanish News}

The existence of gazettes in Spanish published in the Northern Provinces did not go unnoticed by either the printers of the Spanish Low Countries or the authorities of His Catholic Majesty. Some leading Sephardic Jews resident in Amsterdam were from Brussels, a city where they doubtless continued to maintain contacts. Brussels, capital of Spanish and Catholic Flanders, joined the different places where news periodicals were published in Dutch and French, beginning with the Nieuwe Tijdinghen of Abraham Verhoeven in $1620^{\text {vii }}$. In both the Protestant Low Countries and the Catholic Low Countries (Flanders) it was common practice to publish news periodicals in several languages. The 
most widely translated newspaper in Europe was the Gazette d'Amsterdam, above all in France (Rétat, 2001). In Spain, in Catalonia especially, several individual issues were published, translated with the titles Gazeta de Ámsterdam [Amsterdam Gazette], by Jacinto Andreu and Rafael Figueró in 1673, 1684, 1720 and 1735, and Nuevas de Amsterdam [News of Amsterdam] by Joseph Moyà in 1685.

One of the printers in Spanish Flanders who published newssheets, singly or with others, was Pierre (or Pedro) de Cleyn. Between 1666 and 1685, he joined Guillaume Scheybels to publish the Rélations veritable. It was normal for Cleyn - who translated or commissioned translations of letters in different languages - to work in Dutch, French, German and Spanish. Like Antwerp, Brussels was an important node of postal communications, and both were a crossroad of the postal service that joined Atlantic Europe with Central Europe and the Catholic and Protestant lands. The flow of news from Spain to the Low Countries had improved notably between the middle of the century and its close; while in 1653 the news that came from Madrid took between 30 and 40 days to arrive (Arblaster, 2006: 27); when Cleyn published his newspaper in Spanish it took considerably less time. Cleyn, probably at the request of the Spanish authorities judging by the difficulties and penuries that he laments on occasion in its pages, decided to begin publication of the Noticias Principales y Verdaderas, and thus ceased to print the Relations Véritables. In order to do so, he now had not only a licence but a privilege.

The exact date of publication of this important gazette is not known. The first number that is preserved, belonging to the National Library of France, is from 1685, but it is clear from its content that it had already been published and distributed in Flanders and Spain for some time. A collection including several correlative issues from the years 1685 and 1686 has been located in the National Library of France, and four issues of the Noticias Principales $y$ Verdaderas from 1689 in the National Library of Madrid. The largest collection, 64 copies from the years 1688 to 1691, is preserved in the Hemeroteca Municipal de Madrid (13 from 1688, 19 from 1689, 7 from 1690 and 25 from 1691). It always opened with brief news stories from Spain, generally referring to the royal family and their court, and it regularly carried news from Germany, Italy, the North (proceeding from Hamburg), England, Holland and France. Finally, in smaller print, information from Brussels, linked to the 
official Spanish sources. Unlike the subsequent re-editions in San Sebastian, the Noticias Principales y Verdaderas of Pedro de Cleyn lacked correlative numbering.

The aim was for it to be weekly, the shortest periodicity in those times, but it ended up having a fortnightly character. It was a weekly for a certain time (from mid-1685 onwards), although its most normal periodicity was fortnightly, certainly in order to permit the arrival of the news from Spain that opened each issue viii. There was thus no gazette in Spain that provided news about the kingdom itself. This publication was, however, aimed at the Spanish market, as is shown in the first issue that we know of, dating from $24^{\text {th }}$ July 1685 : "There being complaints that the news about Spain is out of date, as it is not published except every fortnight, and continuous novelties are occurring, these are offered every eight days, with permission, having started on the 18th of the current month (July 1685), in order to satisfy the Spanish curiosity." This newspaper was also aimed at the Brussels market, as each issue closed with a recent news story from the Flemish city itself.

We know a little about the workings of the gazettes in which P. de Cleyn participated. Relations Véritables was made up of bulletins sent by correspondents stationed in the European capitals: Rome, Venice, Genova and Milan in Italy, Hamburg as the principal supplier of news from the North, London, Paris and Vienna. And also from Madrid, which was significant. The same stories, translated into Spanish and aimed at the Spanish market, were used to fill the Noticias Principales y Verdaderas. A comparison between closely dated issues of the Relations Véritables and the Noticias Principales y Verdaderas corroborates this assertion. The Spanish-language gazette was printed one day before, and was shorter (four pages) than the gazette in French, which generally consisted of eight pages. The news stories were not necessarily repeated in the two gazettes, although this did happen frequently with stories about Spain, which of course tells us that they had a common origin.

On Cleyn's death in 1690, his widow kept on the news office but ceded the printing to Pedro de Debbeleer, which shows that both activities were already specialised. It seems that the writing up (and translation and adaptation) of the news that arrived from different sources (other gazettes, letters) was the responsibility of a single person, a "journalist" whose name is today unknown to us, since in the issue corresponding to the news stories 
that had occurred between $5^{\text {th }}$ June and $3^{\text {rd }}$ July 1691, the reader is warned that "due to the serious accident that befell the Author on $11^{\text {th }}$ June, the news for the fortnight was not given in the last letter, which is now briefly summarised, together with those acquired subsequently. And for the $15^{\text {th }}$ of the current month, or a bit earlier, the first part of the abbreviated History of this year of the last Decade of the iron century is promised, with distinction and brevity, which will continue if it is well received." A demanding trade, for sure, and a badly paid one, since that "journalist" found himself obliged to compose gazettes, newssheets and chronicles without rest.

In the final number of Cleyn's Noticias Principales $y$ Verdaderas that is known one can read: "The limited dispatch of these News Stories, and the scant assistance provided to he who gathers them, smother the great desire to satisfy public curiosity, and also make it impossible to publish many works, on which fatiguing labor is incessantly done, despite ailments and age, amongst them the historical compilation of the events and wars of Hungary, from their start until the current year".

With respect to its design, it was notably poorer than that of its neighboring Dutch gazettes. The masthead is placed at the top of the first of the four quarto pages that made up the newspaper. As a subtitle, which was customary in that period, the date of the news is given: "From 18 to 24 July 1685", for example. The text is arranged in a single column, and the first letter is a large capital letter. First, as one would expect, the news of Spain, always of an official character. Next, news about Italy, Germany, "the North" (Hamburg, Poland, Moscow, etc.), England, Holland and France, always very brief. Only later, in 1696, was news included about the Nordic countries; these were news stories dated in "Stockholm" and "Coppenhaguen", where serious differences had arisen between the Crown (Christian V) and the Duke of Hostein. The issues covered by the Noticias Principales $y$ Verdaderas were basically of a political and military type, in particular referring to the Holy League (in fact "Advances of the Holy League" is the heading of the majority of the numbers of this gazette), "The Coronation of the most August Archduke Joseph King of Hungary", expeditions sent by the English Crown "against the south sea pirates", etc. Each news story, without a date, is headed by a "From [the country concerned]" in versal. A large part of the final page is dedicated to news stories about Brussels, generally in smaller type than the rest. 


\subsection{From Brussels to the Peninsula: the Reception in Spain of Cleyn's Gazette}

In the Spanish news panorama, which the production of printed newspapers was beginning to structure, the Noticias Principales y Verdaderas that were published every fortnight in Brussels must have been a salutary example. Various reimpressions of the newspaper exist in three Spanish cities: Seville, Barcelona and San Sebastián.

In Barcelona, it was reprinted in January 1685 not as a periodical but as an occasional title, by Joseph Moyà, who did not expurgate the news about Spain or Brussels on two occasions that we know of, and by an anonymous printer that same year in May.

A fourth issue dates from September 1686; the Spanish news is expurgated ${ }^{\mathrm{ix}}$. Its pages are numbered (from 139 to 142), which allows us to suppose that it forms part of a collection that is at least serialised if not periodical. It has no printer's imprint.

There is, as far as we know, another reimpression in Seville. It dates from 1687, and the news stories referring to Brussels and Spain have also been expurgated. It also seems to be an occasional reimpression, although a carefully executed one as the design of the copy is superior to that of the original.

Other postal services, according to Paul Arblaster, competed with the official post of the Tassis, especially those that brought correspondence from Antwerp and Paris to Spain via Bordeaux (Arblaster, 2006: 21). It was precisely in Bordeaux where the sons of Martín de Huarte studied. He was the first printer of the Basque province of Guipúzcoa, whose typography was brought from Amsterdam. It was in the year 1667 when he requested permission to be the printer of the province, receiving licence - that is to say the monopoly - to print all types of papers.

Martín de Huarte died in 1677, and the province decided to appoint his widow, Francisca de Aculodi, as its printer, until one of her sons "should reach the state of being able to take charge". This occurred in 1686, when it is known that Pedro, the firstborn, opened another establishment and was appointed as the province's official printer in 1688. The mother ${ }^{\mathrm{x}}$, meanwhile, requested the same position for her other son, Bernardo, arguing that he had been in France studying the typographical art, Latin and French. By whatever means, the 
Huarte family controlled all of the news market of a large part of the North of Spain. There is information about his activity until 1729, when Pedro and Bernardo de Huarte moved to Pamplona. No other news periodicals would appear in San Sebastián until the beginning of the nineteenth century.

It was Pedro de Huarte who had the idea of printing, punctually every fortnight, a reimpression of the Noticias Principales y Verdaderas of P. de Cleyn. It is known that every fortnight between 1687 and 1704, at least, the Huartes ${ }^{\mathrm{xi}}$ published an edition from which Spanish and Brussels news was expurgated, and which at times was enriched with news stories, always foreign, which arrived in San Sebastián overland from Flanders, or by sea from London ${ }^{x i i}$.

To satisfy the curiosity and thirst for reading up-to-date information, Pedro de Huarte managed to publish another fortnightly gazette in those weeks when the reedition of Cleyn did not come out, titled Noticias Extraordinarias del Norte [Extraordinary News of the North], of which we have knowledge of a good number of issues from 1688 to 1689. This seems to have been an original production, which would confirm other indications of the existence of one or several news offices in Guipúzcoa (similar to those already identified in Holland by Couvée, 1951). Finally, now in the eighteenth century, just when a bourgeois commercial consciousness was starting to emerge around the Compañía Guipuzcoana de Caracas [Guipuzcoan Society of Caracas] and the men who would later create the Sociedad Bascongada de Amigos del País [Basque Society of Friends of the Country] (the first of such characteristics in Spain), there are three issues concerning another weekly gazette, the Extracto de Noticias Universales [Summary of Universal News].

In those same years when Pedro de Huarte feverishly dedicated each week to the production of gazettes, there are more indications of an intense professional activity of collecting and disseminating news in San Sebastián, which was close to the frontier with France and the axis of post from Central Europe. Dated $14^{\text {th }}$ October 1689, a handwritten gazette was produced, titled Novedades de la Europa [Novelties of Europe]. It was written by an unknown journalist, perhaps for the same municipal corporation of Hondarribia that preserves it today. It is not possible to know if the initiative was continued, but certainly the use of the term "each week" implies that it lasted for some time. Since just one handwritten 
issue is known, it is for the time being impossible to determine for how long this effort lasted.

A third piece of evidence demonstrates the effervescence of news activity in San Sebastián, and the news flow generated in that city, in spite of its small size. Between 1686 and 1692, at the height of Pedro de Huarte's newsmongering activity, numerous news stories about all of Europe were published in another weekly Peninsular gazette, the Noticias Generales de Europa, venidas a Barcelona por el Correo de Flandes [General News of Europe, coming to Barcelona by the Flanders Post], dated in San Sebastián. Some news stories are first hand, obtained by anonymous informants in Bayonne or Hondarribia ("from all of these frontiers they report what has become known in France"), but there are also stories proceeding from “a post from Madrid”, brought by a ship's captain from Cadiz, or by letter from Brussels.

\section{Conclusion}

To conclude, at the end of the seventeenth century a consolidation of the flow of information can be witnessed, of which the initiatives that have been examined are a clear example. On the one hand, it seems clear that the postal services (whether official or not) determined the frequency in the reception of news from other parts of Europe, which enabled San Sebastián, due to its proximity to the French frontier and the axes of Flanders and of Seville-Madrid, to have abundant news material available.

On the other hand, everything indicates that there was a specialisation of functions, generally beginning with the figure of the printer, who, like Cleyn in Brussels, had available one "author" of news stories, who gathered, translated, adapted and wrote them up. The syndicate was a normal recourse of the time in London, Brussels or Barcelona.

All of this means that the exchange of information was continuous. One family, such as the Huartes, printers in a small but well situated city like San Sebastián, maintained fluid relations with other cities: like Bordeaux, Amsterdam and Brussels. Besides, they depended on the post of Andalusia via Madrid, and that of London, on the way to the capital and the court, which enabled them to have two additional sources of information. This means that from San Sebastián news was sold to Barcelona, situated on the other postal axis, with the 
result that acquaintance and collaboration amongst the different printers of the Peninsula and its different newspapers was also fluid.

This was, therefore, a complex and dynamic news market, in which the presence of the Spanish language was considerably greater and more important than had been supposed until relatively recently. The state of autarchy in which the monarchy of Felipe IV attempted to keep the internal Spanish news market ${ }^{\text {xiii }}$ was to some extent offset by the impulse provided by the Continent. This meant that there was, as we have seen, a continuous exchange of news in the Spanish language in all of Europe at the end of the century, although it reached Spain with a certain delay when compared to other European countries.

\section{Bibliography}

ARBLASTER, PAUL, "Policy and publishing in the Habsburg Netherlands, 1585-1690", In: DOOLEY, BRENDAN; BARON, SABRINA, eds., The politics of information in Early Modern Europe (London; New York: Routledge, 2001), 179-198.

ARBLASTER, PAUL, "Posts, Newsletters, Newspapers: England in a European system of communications", In: RAYMOND, JOAD, ed., News networks in Seventeenth Century Britain and Europe (London; New York: Routledge, 2006), 19-34.

BASTIANSEN, HENRIK G., "Media history and the study of media systems." Media History, 14, 1 (2008): 95-112.

BOER, HARM DEN, La literatura sefardí de Amsterdam (Alcalá de Henares: Instituto Internacional de Estudios Sefardíes y Andalusíes de la Universidad de Alcalá, 1996).

BOUZA, FERNANDO, Corre manuscrito. Una historia cultural del Siglo de Oro (Madrid: Marcial Pons, 2001).

BRÜGGER, NIELS, "Theoretical Reflections on Media and Media History." In: BRÜGGER, NIELS; KOLSTRUP, SOREN, eds., Media History. Theory, Methods, Analysis (Aarhus: Aarhus University Press, 2002), 33-66.

COUVEE, D.H., Van couranten en courantiers uit de zeventiende en de achtiende eeuw (Amsterdam : C.G.C. Corvey, 1951). 
COUVEÉ, D.H., "The First Coranteers- the Flow of the News in the 1620's." International Communication Gazette 8 (1962): 22-36.

DAHL, FOLKE, "Amsterdam. Earlier Newspaper Centre of Western Europe. New contributions to the history of the first Dutch and French corantos." Het Boek, XXV, 3 (The Hague: Martinus Mijhoff, 1939), 161-198.

DAHL, FOLKE, Dutch corantos 1618-1650. A bibliography. (The Hague: Koninkiljke Bibliotheek, 1946).

DAHL, FOLKE, ed., The Birth of the European Press (Stockholm: The Royal Library, 1960).

DE VIVIO, FILIPPO, "Paolo Sarpi and the Uses of Information in Seventeenth-Century Venice." In: RAYMOND, JOAD, ed., News networks in Seventeenth Century Britain and Europe (London; New York: Routledge, 2004), 35-49.

DÍAZ NOCI, JAVIER and MERCEDES DEL HOYO, El nacimiento del periodismo vasco: Gacetas donostiarras de los siglos XVII y XVIII (San Sebastián: Basque Studies Society, 2003).

DÍAZ NOCI, JAVIER, "Fuentes históricas coetáneas de la liberación de Hondarribia: La construcción de un acontecimiento en la España de Olivares." Mediatika. Cuadernos de Medios de Comunicación (10) (San Sebastián: Basque Studies Society, 2004), 77-107 (http://hedatuz.euskomedia.org/2552/1/10077107.pdf. Accessed: 12 October 2011).

DOOLEY, BRENDAN, ed., The Dissemination of News and the Emergence of Conemporaneity in Early Modern Europe (Cork: University College, 2010).

DOOLEY, BRENDAN; BARON, SABRINA A., eds., The Politics of Information in Early Modern Europe (London; New York: Routledge, 2001).

DOWNIE, J. A., "Periodicals, the Book Trade and the 'Bourgeois Public Sphere'. Media history and the study of media systems.” In: Media History, 14, 1 (2008): 261-274.

ESPEJO, CARMEN, "El impresor sevillano Juan Gómez de Blas y los orígenes de la prensa periódica. La Gazeta Nueva de Sevilla (1661-1667).” In: Zer, 13, 25 (2008): 243-267.

ETTINGHAUSEN, HENRY, "The news in Spain: Relaciones de sucesos in the reigns of Philip III and IV.” European History Quarterly, 14 (1984): 1-20. 
ETTINGHAUSEN, HENRY, La Guerra dels Segadors a través de la premsa de l'época (Barcelona: Curial, 1983).

ETTINGHAUSEN, HENRY, "Politics and the press in Spain." In DOOLEY, BRENDAN; BARON, SABRINA BARON, eds., The politics of information in Early Modern Europe (London; New York: Routledge, 2001).

ETTINGHAUSEN, HENRY; CORDERO, MANUEL, eds., Andrés de Almansa y Mendoza. Obra periodística (Madrid: Castalia, 2002).

GUILLAMET, JAUME, Els orígens de la premsa a Catalunya (Barcelona: Arxiu Municipal, 2003).

HANDOVER, P. M., A history of the London Gazette 1665-1965 (London: Her Majesty's Stationary Office, 1965).

INFELISE, MARIO, Prima dei giornali. Alle origini della pubblica informazione (Venecia: Laterza, 2005).

LAMARQUE, MARÍA PILAR, “Cartas de Francisco Fabro Bremundan al Dr. Diego J. Dormer.” Cuadernos de Historia Jerónimo Zurita, 23-24 (1971): 191-201.

LANKHORST, OTTO, "Newspapers in the Netherlands in the seventeenth century." In DOOLEY, BRENDAN; BARON, SABRINA, eds., The politics of information in Early Modern Europe (London; New York: Routledge, 2001), 151-159.

LETH, GÖRAN, "A protestant public sphere: The early European newspaper press.” In: Studies in newspaper and periodical history 1993 Annual /Westport, Connecticut: Greenwood Press, 1994), 67-90.

MAIER, INGRID; WAUGH, DANIEL C., "The Blowing of the Messiah's Trumpet': Reports about Sabbatai Sevi and Jewish Unrest in 1665-1667.” Paper presented at the Conference 'Places of News: The Creation of International News Networks in Early Modern Times', Bremen, 2007.

PETTEGREE, ANDREW, The Book in the Renaissance (Hew Haven: Yale University Press, 2010).

RAYMOND, JOAD, The invention of the newspaper. English Newsbooks 1641-1649 (Oxford: Clarendon Press, 1996).

RAYMOND, JOAD, ed., News, newspapers, and society in Early Modern Britain (London; Portland, or: Frank Cass, 1999). 
RAYMOND, JOAD, ed., News networks in Seventeenth Century Britain and Europe (London; New York: Routledge 2006).

RETAT, PIERRE, dir., La Gazette d'Amsterdam. Miroir de l'Europe au XVIIIe siècle

(Oxford: Voltaire Foundation, 2001).

SOUSA, JORGE PEDRO, coord., A Gazeta da restauração:Primeiro Periódico Português

(Covilha: LabCom, 2011).

WEBER, JOHANNES, “The early German newspaper. A medium of contemporaneity. “ In

DOOLEY, BRENDAN, ed., The Dissemination of News and the Emergence of

Conemporaneity in Early Modern Europe (Cork: University College, 2010), 69-79.

\footnotetext{
${ }^{\mathrm{i}}$ Jorge Sousa has worked on the origins of Portuguese journalism, from the Cartas Novas, Cartas de Novidades or Cartas de Novas Gerais to the Gazeta, of 1641, by way of the handwritten news collection Relação Universal do que Sucedeu em Portugal e Mais Províncias do Ocidente e Oriente (1626-1628), of Manoel Severim de Faria (Sousa, 2011).

ii This paper attempts to follow the latest currents both in the study of the history of the mass media (Brügger, 2002), and in the study of early journalism (Raymond, 1996; Raymond (ed.), 2004; Dooley, 2010); and to highlight the characteristics of the production and flow of news from the periphery to the Peninsula in the case of the Spanish-language gazettes.

iii A certain business activity at the start of the seventeenth century has been verified that consisted in the translation and handwritten copying of Italian gazettes in Spain. A student of the University of Salamanca, Girolamo da Sommaia, lent out gazettes sent to him from his native Italy to people - at least five - who had them copied by hand for the price of one real (Bouza, 2001: 51, 157). See Diario de un estudiante de Salamanca [Diary of a Salamanca student] (Salamanca: Universidad - Secretariado de Publicaciones e Intercambio Científico, 1977), by Girolamo himself. There seventy references to the loaning out of the Gaceta - at times referred to as from Rome, on others as from Italy, and as Gazzetta, et relatione - and how it passed from hand to hand. At a certain time (p. 491), Girolamo da Sommaia recounts how a certain "don Ambrosio" lent him in his turn the Gaceta Spagnuola, without it being possible for us to determine whether this was printed or handwritten. On another occasion, (page 228), he mentions the nиоие di Valladolid e di Salamanca [news from Valladolid and Salamanca].

iv The other printers of this syndicate were Antonio Lacavalleria, Joseph Forcada, Vicente Surià, Juan Yolis and Joseph Llopis.

$v$ "The new post of Gazetteer has today been the object of laughter, aimed at whoever throws his money away on such a trifle [...] It would be a great position, since it prohibits printing, were it to prohibit anyone in handwritten letters from notifying their friends of the novelties of the court and outside it! Without this circumstance this so-called post would be left without value". Once again, the coexistence of handwritten and printed news becomes apparent.

${ }^{\text {vi }}$ The normal practice was to give another less suspicious city in the printer's imprint, for example Brussels, the capital of Spanish Flanders, or Antwerp, although of course all the books came off de Castro's press in the Dutch capital.

vii A transcription and translation into English (edited by Paul Arblaster) of the majority of the issues from 1622 can be found on WikiNews: http://historyofnews.wikia.com/wiki/Category:Printed_by_Abraham_Verhoeven . See also Arblaster, 2006: $22,24,25$.
} 
viii "Due to the tardiness of the post, as the roads are unusable, it is not possible to let the curious participate in the novelties that are offered about Spain, if there were news of particular interest we would omit it in the following news" it says on 16th January 1691.

${ }^{\text {ix }}$ A complete catalogue and the full text of all the expurgated news from Spain which appeared in the Spanish re-editions of Noticias Principales y Verdaderas, although not in the original newspaper from Brussels, can be found as a special section in Díaz Noci \& Del Hoyo, 2003.

${ }^{x}$ Who was possibly not the mother of Pedro, as the latter's second surname was Manterola.

xi They reached the extreme of publishing two editions of the reimpression of the Noticias Principales $y$ Verdaderas, the issue of $25^{\text {th }}$ October 1688.

xii For example, the news item of $28^{\text {th }}$ June 1688, dated in San Sebastián, on the birth of the Prince of Wales, "by an extraordinary letter with the news sent to Madrid"

xiii Proof of this is that the state's propaganda apparatus was only really set in motion on particular occasions, such as the case of Hondarribia in 1638, but was not used for publishing official newspapers, as happened, for example, in France or England (see Díaz Noci, 2004). 